УДК 342.924

DOI https://doi.org/10.32849/2663-5313/2020.8.27

Сергій Короєд,

докт. юрид. наук, дочент

\title{
РІШЕННЯ ВИЩЕСТОЯЩОГО В ПОРЯДКУ ПІДЛЕГЛОСТІ ОРГАНУ, ПРИЙНЯТЕ ЗА РЕЗУЛЬТАТАМИ РОЗГЛЯДУ СКАРГИ НА РІШЕННЯ НИЖЧЕСТОЯЩОГО ОРГАНУ, ЯК САМОСТІЙНИЙ ПРЕДМЕТ ОСКАРЖЕННЯ В АДМІНІСТРАТИВНОМУ СУДОЧИНСТВІ
}

Визначається правова природа рішення вищестоящого органу в порядку підлеглості, прийняте за результатами адміністративного оскарження рішення нижчестоящого органу, як самостійного предмета оскарження в адміністративному судочинстві. Дається загальнотеоретична характеристика адміністративної юрисдикції з огляду на статус ї суб’єктів та характер змісту юрисдикиійної діяльності. Наводиться аналіз законодавства, яке передбачає можливість адміністративного оскарження до вищестоящого органу в порядку підлеглості рішення нижчестоящого органу. Водночас встановлено, що в одних випадках закон надає можливість оскарження до адміністративного суду саме рішення вищестоящого в порядку підлеглості органу, прийнятого за результатами процедури адміністративного оскарження за скаргою особи на рішення нижчестоящого органу, а в інших випадках закон передбачає оскарження до суду саме первісного рішення. З'ясовано, що вищестоящий в порядку підлеглості орган не може погіршувати становище особи та за результатами розгляду скарги або залишає попереднє рішення нижчестоящого органу без змін, або змінює його. Аргументовано, що рішення нижчестоящого органу та прийняте за результатами його адміністративного оскарження рішення вищестоящого органу варто розглядати як єдине рішення державного органу, який діє від імені держави. У зв'язку із иим доведено, що для особи юридичні наслідки породжуватиме передусім первісне рішення нижчестоящого органу, яким було вирішено по суті відповідне правове питання, оскільки таке первісне рішення буде розглядатись як цілісне рішення з урахуванням внесених до нього змін вищестоящим органом. Обгрунтовується думка, що рішення вищестоящого органу про відмову в задоволенні скарги на рішення нижчестоящого органу взагалі жодних нових негативних юридичних наслідків для особи не створює, а рішення вищестоящого органу про часткове задоволення скарги (без повернення справи на новий розгляд) змінює безпосередньо первісне рішення нижчестоящого органу, яке й буде оскаржуватись особою до адміністративного суду у його незміненій (не скасованій) частині.

Ключові слова: адміністративне судочинство, адміністративна юрисдикція, предмет оскарження, рішення, вищестоящий орган, спосіб захисту, ефективність, юридичні наслідки, порушення прав, відновлення прав.

Постановка проблеми. Раніше ми вже торкались проблем оскарження (перегляду) рішень юрисдикційних органів, але розглядали ці питання в межах цивільного права і процесу в аспекті процедури та особливостей перегляду судом рішень органів, які здійснюють захист цивільних прав (органів нотаріату під час вчинення виконавчих написів, органів опіки та піклування під час вирішення окремих сімейних спорів, місцевих рад під час розгляду окремих земельних споpiв, комісій з трудових спорів) та виступають таким чином юрисдикційними органами. Ми обгрунтовували, що рішення зазначених суб'єктів не є безпосереднім предметом оскарження до суду, оскільки об’єктом судової діяльності буде повторне вирішення спору, який попередньо розглядався одним із вказаних суб'єктів [1].

Із дещо схожою ситуацією ми зіткнулись нещодавно, ознайомившись із постановою Верховного Суду у складі колегії суддів Касаційного адміністративного суду від 27 квітня 2020 року в справі № 360/1050/19 (адміністративне провадження № К/9901/27904/19), в якій Верховний Суд, погодившись із рішеннями судів попередніх інстанцій про визнанням протиправним і скасування рішення обласного управління ДФС (про відмову в реєстрації 
податкової накладної), водночас відмовив в задоволенні позову платника податків в частині визнання протиправним і скасування рішення ДФС України (як вищестоящого в порядку підлеглості органу), прийнятого в порядку адміністративного оскарження, про залишення без задоволення скарги позивача на вищевказане рішення обласного управління ДФС, оскільки воно не $є$ юридично значимим для позивача, адже жодних заходів його реалізації щодо позивача не передбачає, а лише залишає чинним (таким, що має обтяжувальну дію щодо позивача) винесене раніше рішення про відмову в реєстрації податкової накладної.

Виклад основного матеріалу. Вказане рішення Верховного Суду на конкретному прикладі показує неоднозначне розуміння як учасниками адміністративних правовідносин, так й судами правової природи, рішення вищестоящого органу в порядку підлеглості, прийнятого за результатами адміністративного оскарження рішення нижчестоящого органу (так зване відомче оскарження), як самостійного предмета оскарження в адміністративному судочинстві. Це змушує нас більш детально заглибитись в зазначену проблему та розкрити характеристики рішень органів, які розглядають в порядку підлеглості скарги (тобто реалізують адміністративну юрисдикцію) на рішення нижчестоящих органів, та правовий статус вказаних органів, що й ставить за мету наша стаття

Так, передусім, визначимось із загальнотеоретичною характеристикою адміністративної юрисдикції. Юрисдикція, як відомо, $\epsilon$ врегульованою правовими нормами процесуальною діяльністю відповідних суб'єктів, яка здійснюється в позасудовому або судовому порядку з метою розгляду і вирішення правових спорів чи правових питань, а також застосування примусових заходів [2, с. 38]. Юрисдикція - це самостійний вид державної, підзаконної, правозастосовчої, правоохоронної діяльності. Як обов'язкові ознаки цієї діяльності вказується: змагальна процедура вирішення справи; видання юрисдикційного акта у встановленій законом формі і наявність правового спору (правопорушення). При цьому зауважується, що юрисдикція як державно-владна діяльність полягає в застосуванні закону саме до юридичних конфліктів [3, с. 11, 17, 18]. Узагальнена характеристика юрисдикції зводиться за своєю юридичною природою до розгляду i вирішення конфліктних ситуацій, які виникають у процесі застосування матеріальних правових норм, до правової оцінки поведінки конфліктуючих сторін і застосування до сторони, поведінка якої визнається неправомірною, передбачених чинним законодавством заходів юридичного примусу або юридичних санкцій [4, с. 466]. Адміністративну юрисдикцію науковці визначають як адміністративно-процесуальну діяльність, яка здійснюється у позасудовому або судовому порядку з метою розгляду і вирішення адміністративно-правових спорів і застосування адміністративно-примусових заходів. Як предмет юрисдикційної діяльності вчені називають конкретні адміністративно-правові спори. Такого роду спори виникають не тільки за ініціативою керованої сторони, а також за ініціативою керуючої сторони (наприклад, при порушенні справи про притягнення громадян до адміністративної відповідальності) [5, с. 405, 413-414]. На думку вчених, необхідність визначення сутності поняття «юрисдикція» випливає 3 поділу всього масиву адміністративних проваджень на адміністративно-юрисдикційні та адміністративно-регулятивні. Щодо адміністративно-юрисдикційних проваджень, то це провадження у справах про адміністративні правопорушення, виконавче провадження, провадження щодо вжиття заходів адміністративного примусу, дисциплінарне провадження, провадження за скаргами та інші. Усі ці провадження є провадженнями з вирішення спору про права, а їх результат накладення стягнення і відновлення порушених правовідносин [6, с. 282].

3 огляду на характер змісту юрисдикційної діяльності (враховуючи широку концепцію розуміння адміністративної юрисдикції) та повноваження суб'єктів юрисдикції в юридичній літературі виділяються такі основні властивості юрисдикції: а) наявність правового спору (правопорушення): юрисдикція виникає лише тоді, коли необхідно вирішити спір про право, поновити порушені права; застосувати відповідальність; б) оскільки юрисдикція є способом вирішення правових конфліктів, вона передбачає необхідність прийняття остаточного рішення. Юрисдикційний акт у конкретній справі означає, по суті, вирішення правового спору. Якщо ж йдеться про правопорушення, в такому акті можуть бути передбачені правові санкції; в) юрисдикційний орган не є учасником спірних матеріальних правовідносин [7, с. 24-25].

Отже, юрисдикція, зокрема адміністративна, за суб'єктом може бути як судовою, так і позасудовою, а за предметом - як розглядом справ про правопорушення і накладення санкцій, так і розглядом скарг на рішення органів про притягнення до відповідальності або вирішення скарг на рішення органів управління, які порушують права громадян. 
Аналіз законодавства свідчить, що адміністративне оскарження (оскарження в адміністративному порядку, або так зване «відомче оскарження») до вищестоящого органу в порядку підлеглості рішення нижчестоящого органу передбачено, зокрема:

- положеннями Кодексу України про адміністративне правопорушення (далі КУпАП), які встановлюють можливість оскарження постанови органу (посадової особи) про накладення адміністративного стягнення, постанови за справою про адміністративне правопорушення у сфері забезпечення безпеки дорожнього руху, зафіксоване в автоматичному режимі, у вищестоящий орган (вищестоящій посадовій особі) (п. 2 ч. 1 ст. 288 КУпАП);

- положеннями Митного кодексу України (далі - МК України), які встановлюють можливість оскарження рішення, дії або бездіяльності митних органів, їх посадових осіб та інших працівників, якщо особа вважає, що цими рішеннями, діями або бездіяльністю

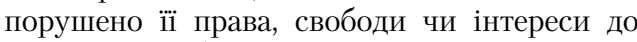
посадових осіб та органів вищого рівня (ст. 24, 25 МК України). Положеннями МК України також передбачене адміністративне оскарження в справах про притягнення до адміністративної відповідальності за порушення митних правил - до центрального органу виконавчої влади, що реалізує державну митну політику (ч. 1 ст. 529 МК України);

- положеннями Податкового кодексу України (далі - ПК України), які встановлюють можливість оскарження в адміністративному порядку рішень контролюючого органу до контролюючого органу вищого рівня (п. 56.1., 56.2., 56.3. ст. 56 ПК України);

- положеннями Закону України «Про звернення громадян», які встановлюють можливість подання скарги на рішення, що оскаржувалось, у порядку підлеглості вищому органу або посадовій особі (ст. 16, 17 вказаного Закону).

Таким чином, положеннями зазначених законів передбачена можливість заінтересованим суб'єктам скористатися альтернативною - позасудовою процедурою оскарження рішення суб'єкта владних повноважень у сфері управлінської діяльності, а після використання такої процедури адміністративного оскарження (до вищого органу в порядку підлеглості) на підставі ст. 55 Конституції України та ст. 5 Кодексу адміністративного судочинства України (далі - КАС України) звернутись із адміністративним позовом до адміністративного суду.

До вищестоящого в порядку підлеглості органу заінтересованою особою може бути оскаржене прийняте щодо такої особи рішення нижчестоящого органу у сфері управлінської діяльності, яким: а) порушено або порушуються пї права і свободи; б) створено або створюються перепони для реалізації особою своїх конституційних прав чи свобод (або вжиті заходи щодо їх реалізації є недостатніми); в) на особу покладено обов'язки, не передбачені законодавством, або передбачені, але без урахування конкретних обставин, за яких ці обов'язки повинні покладатися, або вони покладені не уповноваженими на це особою чи органом; г) особу притягнуто до відповідальності, не передбаченої законом, або до неї застосовано стягнення за відсутності передбачених законом підстав чи неправомочною службовою особою (органом) (п. 5 постанови Пленуму Верховного Суду України від 03.12.1997 № 13 «Про практику розгляду судами справ за скаргами на рішення, дії чи бездіяльність органів державної влади, органів місцевого самоврядування, юридичних, посадових і службових осіб у сфері управлінської діяльності, які порушують права та свободи громадян»).

Водночас законодавець залишається дещо непослідовним у питанні щодо юридичної можливості та необхідності оскарження такого рішення вищестоящого в порядку підлеглості органу, прийнятого за результатами розгляду скарги заінтересованої особи на рішення нижчестоящого органу, що, на нашу думку, й створює правову невизначеність в можливості його оскарження до адміністративного суду та визнання в судовому порядку такого рішення вищестоящого органу протиправним i його скасування паралельно із визнанням протиправним i скасуванням первісного рішення органу управління (нижчестоящого органу).

Так, наприклад, ст. 17 Закону України «Про звернення громадян» передбачає, що рішення вищого державного органу, який розглядав скаргу, в разі незгоди з ним громадянина може бути оскаржено до суду в термін, передбачений законодавством України.

Пунктом 56.10. ст. 56 ПК України теж передбачено, що рішення центрального органу виконавчої влади, що реалізує державну податкову політику, та рішення центрального органу виконавчої влади, що реалізує державну митну політику, прийняті за розглядом скарги платника податків, є остаточними і не підлягають подальшому адміністративному оскарженню, але можуть бути оскаржені в судовому порядку.

Статтею 529 МК України закріплено, що постанова центрального органу виконавчої влади, що реалізує державну митну політику, у справі про порушення митних 
правил, а також його постанова по скарзі на постанову митниці у такій справі можуть бути оскаржені до місцевого загального суду як адміністративного суду в порядку, передбаченому Кодексом адміністративного судочинства України.

Тобто в наведених випадках мова йде про можливість оскарження до адміністративного суду саме рішення вищестоящого в порядку підлеглості органу, прийнятого за результатами процедури адміністративного оскарження за скаргою особи на рішення нижчестоящого органу.

Водночас ст. 288 КУпАП передбачає, що постанову органу (посадової особи) про накладення адміністративного стягнення може бути оскаржено у вищестоящий орган (вищестоящій посадовій особі) або в районний, районний у місті, міський чи міськрайонний суд, у порядку, визначеному Кодексом адміністративного судочинства України, з особливостями, встановленими цим Кодексом.

Проте норми КУ АП не передбачають безпосередньої можливості самостійного оскарження до адміністративного суду рішення вищестоящого органу, прийнятого за результатами розгляду скарги особи на постанову нижчестоящого органу в справі про адміністративне правопорушення про накладення адміністративного стягнення. Хоча для себе ми розуміємо, що таке право безпосередньо закріплене у ст. 55 Конституції України.

Як випливає зі змісту наведеної на початку нашої статті постанови Верховного Суду від 27 квітня 2020 року в справі № $360 / 1050 / 19,3$ огляду на положення ст. 5 КАС України, обов'язковою умовою надання правового захисту судом $€$ наявність відповідного порушення суб'єктом владних повноважень прав, свобод або інтересів особи на момент її звернення до суду. Порушення має бути реальним, стосуватися (зачіпати), зазвичай, індивідуально виражених прав чи інтересів особи, яка стверджує про їх порушення. При цьому неодмінною ознакою порушення права особи є зміна стану їі суб єктивних прав та обов `язків, тобто припинення чи неможливість реалізації її права та/або виникнення додаткового обов'язку. Так, рішення суб'єкта владних повноважень $є$ такими, що порушує права і свободи особи в тому разі, якщо, по-перше, такі рішення прийняті владним суб'єктом поза межами визначеної законом компетенції, а по-друге, оспорювані рішення є юридично значимими, тобто такими, що мають безпосередній вплив на суб'єктивні права та обов'язки особи шляхом позбавлення можливості реалізувати належне цій особі право або шляхом покладення на цю особу будь-якого обов'язку.
В аспекті зазначеної правової позиції Верховного Суду якраз і постає питання про юридичну необхідність окремого (додаткового) оскарження до адміністративного суду рішення вищестоящого в порядку підлеглості органу за результатами розгляду скарги особи на рішення нижчестоящого органу. Відповідь на це питання залежить передусім від відповіді на те, які ж саме негативні (або більш негативні) правові наслідки для особи (у порівнянні з рішенням нижчестоящого органу) може спричинити рішення вищестоящого органу, прийняте за результатами розгляду скарги особи на рішення нижчестоящого органу.

Так, наприклад, у провадженні у справі про адміністративне правопорушення орган (посадова особа) під час розгляду скарги на постанову по справі про адміністративне правопорушення перевіряє законність і обгрунтованість винесеної постанови і приймає одне 3 таких рішень: 1) залишає постанову без зміни, а скаргу без задоволення; 2) скасовує постанову і надсилає справу на новий розгляд; 3) скасовує постанову і закриває справу; 4) змінює захід стягнення в межах, передбачених нормативним актом про відповідальність за адміністративне правопорушення, з тим, однак, щоб стягнення не було посилено (ст. 293 КУ ПАП).

У справі про порушення митних правил законність та обгрунтованість постанови можуть бути перевірені центральним органом виконавчої влади, що реалізує державну митну політику. За результатами перевірки центральний орган виконавчої влади, що реалізує державну митну політику, що проводив перевірку, приймає одне 3 таких рішень: 1) про залишення постанови без змін, а скарги - без задоволення; 2) про скасування постанови і надіслання справи на новий розгляд; 3) про скасування постанови та закриття справи; 4) про зміну виду адміністративного стягнення в межах відповідальності, передбаченої за відповідне порушення митних правил, $з$ тим, однак, щоб це стягнення не було посилено (ст. 530 МК України).

Під час процедури адміністративного оскарження рішення контролюючого (податкового) органу Податковий кодекс України не визначає чіткого переліку рішень, які приймає контролюючий орган вищого рівня за результатами розгляду скарги платника податків на податкове повідомлення-рішення. Проте зі змісту положень ст. 55 і 56 ПК України випливає, що контролюючий орган вищого рівня за результатами процедури адміністративного оскарження за скаргою платника податків на податкове повідомлення-рішення може задовольнити 
таку скаргу платника податків повністю або частково чи відмовити в її задоволенні. Разом із тим визначити нове податкове зобов'язання чи збільшити суму оскаржуваного податкового зобов'язання контролюючий орган вищого рівня не може.

Тобто можна зробити висновок, що рішення вищестоящого в порядку підлеглості органу, прийняте в процедурі адміністративного оскарження за результатами розгляду скарги особи на рішення нижчестоящого органу, не може погіршувати становище особи (посилювати відповідальність особи чи спричиняти більш негативні для особи наслідки в порівнянні із рішенням нижчестоящого органу, яке оскаржується).

Як ми бачимо, в усіх вищезазначених випадках вищестоящий в порядку підлеглості орган за результатами розгляду скарги або залишає попереднє рішення нижчестоящого органу без змін, або змінюе його. При цьому рішення нижчестоящого органу та прийняте за результатами його адміністративного оскарження рішення вищестоящого органу варто розглядати як єдине рішення державного органу (який є частиною державного механізму), оскільки, як ми вже встановили раніше, у випадку застосування процедури адміністративного оскарження діє принцип «єдиної позиції» державного органу (держави) в цілому (незалежно від позицій нижчестоящих і вищестоящих посадових осіб одного органу) у відносинах із громадянином [8, с. 115].

Тому для особи юридичні наслідки породжуватиме передусім первісне рішення нижчестоящого органу, яким було вирішено по суті відповідне правове питання (розглянуто по суті заяву чи скаргу особи) чи застосовано юридичну відповідальність, оскільки таке первісне рішення буде розглядатись як цілісне рішення з урахуванням внесених до нього змін вищестоящим органом.

Саме із цих міркувань мабуть й виходив законодавець, коли, наприклад, у Митному кодексі України закріпив правило, згідно 3 яким якщо рішення, дії або бездіяльність митного органу або його посадової особи одночасно оскаржуються до органу (посадової особи) вищого рівня та до суду і суд відкриває провадження у справі, розгляд скарги органом (посадовою особою) вищого рівня припиняється (ст. 29, 529 МК України).

I це зрозуміло, адже до адміністративного суду подається адміністративний позов про оскарження саме первісного рішення, яке безпосередньо й спричиняє негативні юридичні наслідки для особи. Тобто в цьому випадку при одночасному оскарженні рішення як до вищестоящого органу, так і до суду, відбувається заміна позасудової юрисдикції на судову, адже держава надала судам остаточну найвищу юрисдикцію у вирішенні юридичних спорів питань, а їх рішення наділила законною силою [8, с. 114].

\section{Висновки}

Таким чином, наведені вище аргументи свідчать, що, з одного боку, особа має право в силу ст. 55 Конституції України і ст. 5 КАС України оскаржити до адміністративного суду безпосередньо те рішення вищестоящого в порядку підлеглості органу, яке прийняте за результатами розгляду скарги на рішення нижчестоящого органу, а з іншого боку, законодавець виключає необхідність, а відтак і юридичну можливість визнання судом такого рішення протиправним і його скасування як самостійний спосіб захисту прав позивача, оскільки рішення вищестоящого органу про відмову в задоволенні скарги на рішення нижчестоящого органу взагалі жодних нових негативних юридичних наслідків для особи не створює, а рішення вищестоящого органу про часткове задоволення скарги (якщо рішення нижчестоящого органу змінюється по суті без повернення справи на новий розгляд нижчестоящому органу) змінює безпосередньо первісне рішення нижчестоящого органу (зменшує негативні наслідки), яке й буде оскаржуватись особою до адміністративного суду у його незміненій (чинній, не скасованій) частині (адже немає сенсу оскаржувати до суду рішення вищестоящого органу - в частині часткового задоволення скарги особи, оскільки таке рішення вищестоящого органу $\epsilon$ прийнятим на користь особи, а тому у випадку його оскарження буде відсутній предмет спору).

\section{Список використаних джерел:}

1. Короєд С.О. Концепція судового перегляду рішень юрисдикційних органів в цивільному судочинстві. Держава і право : Збірник наукових пращь. Серія Юридичні науки. Випуск 72 / Ін-т держави і права ім. В.М. Корецького НАН України. Київ : Вид-во «Юридична думка», 2016. С. 255-266.

2. Петухов П.А. Юрисдикционная деятельность в советском государственном управлении. Правоведение. 1980. № 5. С. 37-43.

3. Шергин А.П. Административная юрисдикция. Москва, 1979. 144 с.

4. Козлов Ю.М. Административное право : учебник. Москва : Юристъ, 2007. 554 с.

5. Административное право : учебник / Под ред. Ю.М. Козлова и Л.Л. Попова. Москва, 2001. $726 \mathrm{c}$.

6. Колпаков В.К. Адміністративне право України : підручник / В.К. Колпаков, О.В. Кузьменко. Київ : Юрінком Інтер, 2003. 544 с. 
7. Короєд С.О. Судовий розгляд справ про адміністративні проступки : дис. ... канд. юрид. Наук : 12.00 .07 ; Київ. нац. ун-т внутр. справ. Київ, 2009. 277 арк.

8. Лошицький М.В., Короєд С.О. Позбавлення суб'єктів владних повноважень права на апеляційне оскарження судових рішень в адмі- ністративному судочинстві як напрям забезпечення ефективності адміністративної юстиції. Держава $i$ право: Збірник наукових пращь. Юридичні і політичні науки. Випуск 85 ; Ін-т держави і права імені В. М. Корецького НАН України. Київ : Вид-во «Юридична думка», 2019 C. 108-118.

Serhii Koroied. The decision of the higher body in the order of subordination, made as a result of consideration of the complaint against the decision of the lower body, as an independent subject of appeal in administrative proceedings

The legal nature of the decision of a higher body in the order of subordination, made as a result of an administrative appeal against the decision of a lower body, as an independent subject of appeal in administrative proceedings. The general theoretical characteristics of administrative jurisdiction in view of the status of its subjects and the nature of the content of jurisdictional activity are given. It is provided an analysis of the legislation, which provides for the possibility of an administrative appeal to a higher body, in the order of subordination, of the decision of a lower body. At the same time, it is established that in some cases the law provides for the possibility to appeal to an administrative court against a decision of a higher body adopted as a result of an administrative appeal procedure on a person's complaint against a lower body's decision, and in other cases, the law provides opportunity for appeal to the court against the original decision. It was found that the higher body in the order of subordination cannot worsen the situation of the person and as a result of the reviewing of complaint either leaves the previous decision of the lower body unchanged, or changes it. It is argued that the decision of a lower body and the decision of a higher body adopted as a result of its administrative appeal should be considered as the only decision of a state body acting on behalf of the state. In this regard, it is proved that for a person the legal consequences will be generated primarily by the initial decision of the lower body, which resolved the essentially relevant legal issue, as such an initial decision will be considered as a holistic decision taking into account changes adopted to this decision by the higher body. The opinion is substantiated that the decision of the higher body to refuse to satisfy the complaint against the decision of the lower body does not create any new negative legal consequences for the person, and the decision of the higher body to partially satisfy the complaint (without returning the case for reconsideration) directly changes the original decision, which will be appealed by a person to the administrative court in its unchanged (not canceled) part.

Key words: administrative proceedings, administrative jurisdiction, subject of appeal, decision, higher body, method of protection, efficiency, legal consequences, violation of rights, restoration of rights. 